\title{
NOTES ON THE THICK-SHELLED RIVER MUSSEL UNIO CRASSUS PHILIPSSON, 1788 (BIVALVIA: UNIONIDAE) IN STRADOMKA (SOUTHERN POLAND), A TRIBUTARY OF THE RABA RIVER
}

\author{
MACIEJ BONK
}

\begin{abstract}
Institute of Nature Conservation, Polish Academy of Sciences, Al. A. Mickiewicza 33, 31-120 Cracow, Poland

Institute of Zoology, Department of Entomology, Jagiellonian University, Gronostajowa 9, 30-387 Cracow, Poland (e-mail: bonk.maciej@gmail.com)
\end{abstract}

\begin{abstract}
This contribution presents new data on the occurrence of the thick-shelled river mussel Unio crassus in the Stradomka river and its tributaries (S. Poland), not surveyed earlier. Live specimens and empty shells were found in 14 localities, mostly in the Stradomka river.
\end{abstract}

KEY WORDS: thick-shelled river mussel, Unio crassus, Stradomka, Raba tributary

\section{INTRODUCTION}

The thick-shelled river mussel Unio crassus Philipsson, 1788 is a large unionid (Bivalvia: Unionidae) species. Though it is morphologically similar to other unionid mussels with which it often co-occurs, several shell characters make it possible to identify the species in the field. U. crassus is regarded as a primarily fluviatile species. It inhabits lowland and upland rivers, both large and small (LOPES-LimA et al. 2016). As in other species of Unio, its reproduction requires obligatory fish hosts; the larvae (glochidia) feed mostly on gills. Several fish species are hosts to glochidia of U. crassus: Leuciscus leuciscus, L. cephalus, Scardinius erythrophthalmus, Cottus gobio (ZAJAC 2010 and references therein, DOUDA et al. 2012, 2014), Phoxinus phoxinus and some other species (TAEUBERT et al. 2012). The thick-shelled river mussel used to be common in Europe, including Poland; later water pollution and river regulation led to a decrease in its abundance (ZAJĄC 2004, 2010). The river bottom types preferred by $U$. crassus include sand, gravel, stone and clay.

The present-day distribution of $U$. crassus in Poland includes Pomerania, Mazurian and Suwałki
Lake Districts (Romincka Forest, MARZEC 2010; Krutynia river-lake system, LEWANDOWSKI \& JAKUBIK 2014), tributaries of the Warta, Pilica and Nida rivers (ZAJAC 2010), rivers of the Carpathian foothills (Jasiołka and Cedron, ZAJĄC 2010), as well as Podlasie and Mazowia regions (Liwiec river, KORYCIŃSKA 2002). The few unpublished records include Korzenna (tributary of Kacanka) and Tuszymka rivers (S. Poland, M. BONK 2015-2016 unpublished). Several other sites in which only empty shells were found (Jasieńka - tributary to Strwiąż, Wschodnia near Połaniec, Zgłowiączka near Wieniec and Vistula in Włocławek; BONK 2015, unpublished) need to be verified in the context of viable population existence.

The thick-shelled river mussel is legally protected in Poland. It is also included in Annex II of the EU Habitats Directive. In Poland it is regarded as endangered (ZAJĄC 2004). Recently, it was included in the National Nature Monitoring of Annexes II and IV of the EU Habitats Directive species (ZAJĄC 2010).

This note contributes new data on the occurrence of the thick-shelled river mussel in the Stradomka river, where it was not previously recorded. 


\section{METHODS}

\section{STUDY AREA}

Stradomka is a right bank tributary of the Raba river. It starts in the Beskid Wyspowy and exhibits mostly montane or submontane character. In its lower part the substratum is mainly sand, gravel and clay. The river channel is mostly regulated by large stone embankments. However, many natural hydro-morphological elements are still present. The three largest right-bank tributaries of the Stradomka river: Tarnawka, Sanecki (Trzciański) and Polanka streams, were also searched for the thick-shelled river mussel.

\section{MUSSEL DETECTION}

This contribution presents data collected irregularly in shallow and accessible parts of the mentioned watercourses. Visual surveys in clear transparent water were conducted from April to September 2016.
The length of the controlled river sections ranged from 10 to $700 \mathrm{~m}$.

Usually, only one or several mussels at each site were dug out from the substratum and identified, to avoid unnecessary disturbance of the mussels. It was assumed that the other bivalves buried in the substratum with only siphons protruding were also thick-shelled river mussels, since 1) in the Polish mountain and submontane rivers other unionids usually do not occur, 2) in all surveyed sites the first mussels found were always thick-shelled river mussels, 3 ) no other unionids or empty shells were found in the reported sites, 4) the species is typically found almost entirely dug into the substratum showing only siphons. However, it cannot be excluded that small numbers of other Unio or Anodonta were present in the area. Nonetheless, this would have only affected the number of recorded mussels but not the number of localities because the thick-shelled river mussel was always present.

\section{RESULTS}

I found 14 localities inhabited by U.crassus (Fig. 1, Table 1). Nine were located in the Stradomka river, two in the Trzciański (Sanecki) stream, one in the Tarnawka river and one in the Polanka stream. Most of the sites contained at least one live specimen each (Fig. 2); only one empty shell was found in the highest situated site in the Trzciański (Sanecki) stream. In the Stradomka river the species reaches at least

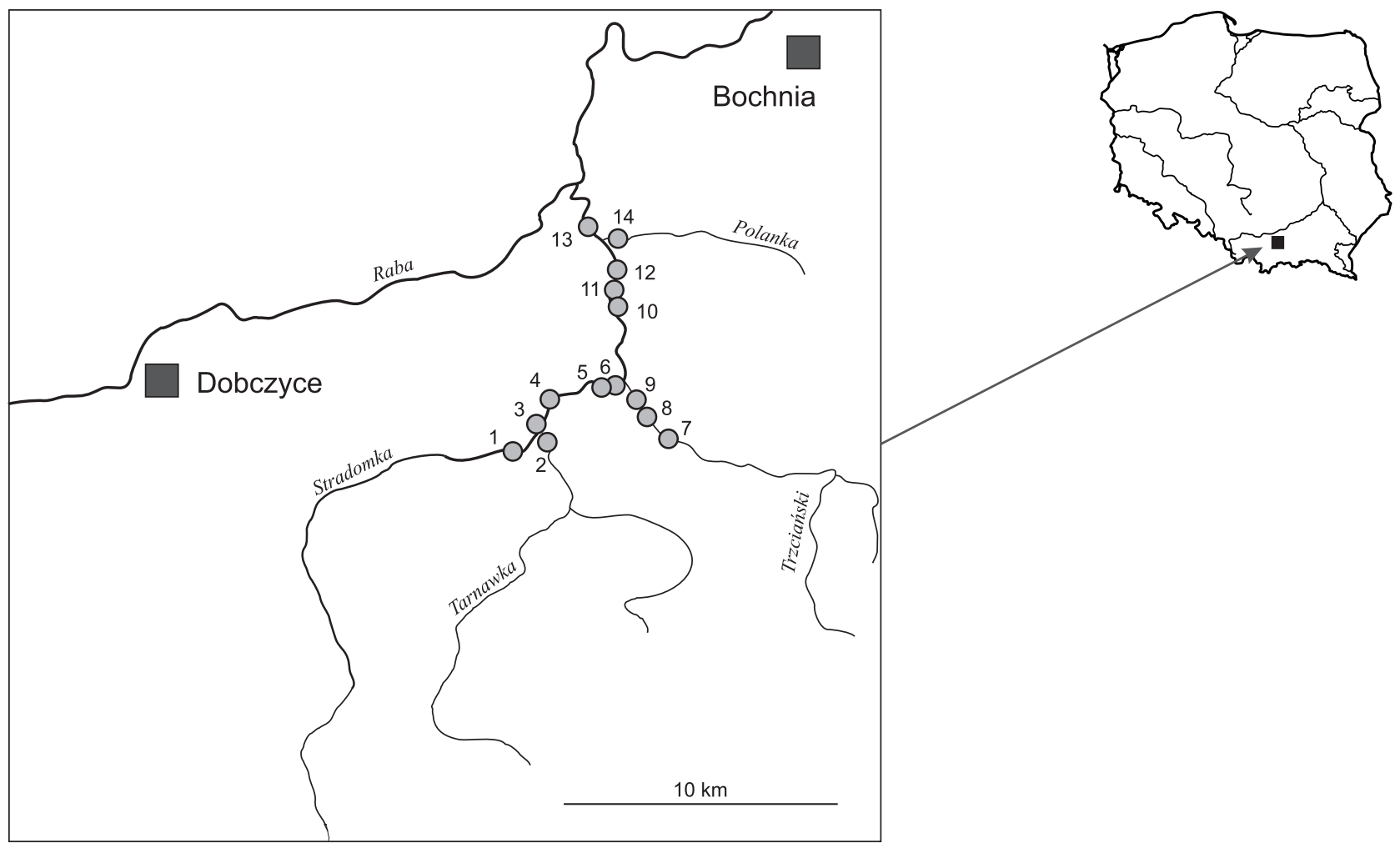

Fig. 1. Distribution of the thick-shelled river mussel Unio crassus Philipsson, 1788 in the Stradomka river and its tributaries. Circles - new sites of Unio crassus Philipsson, 1788 


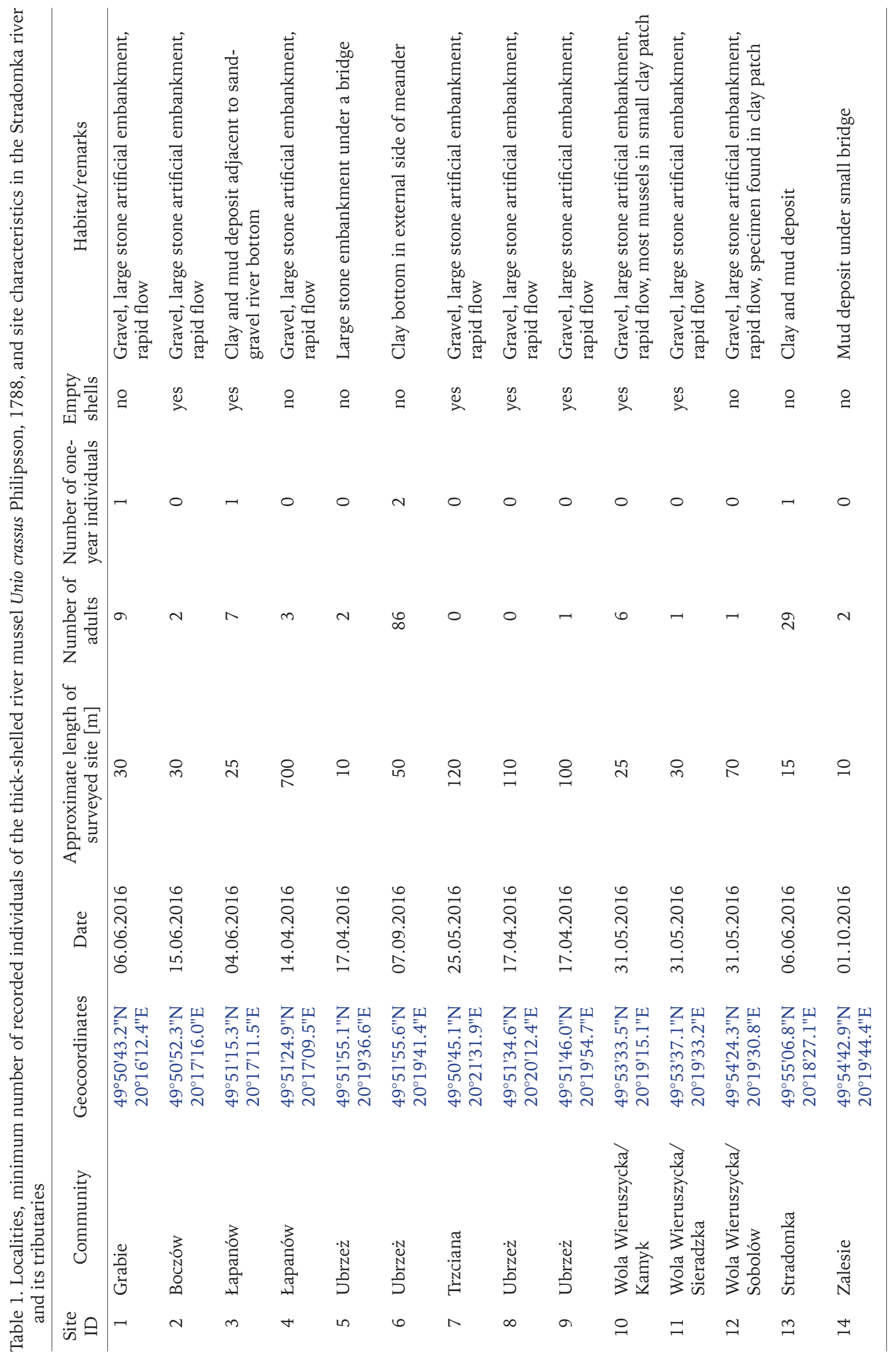




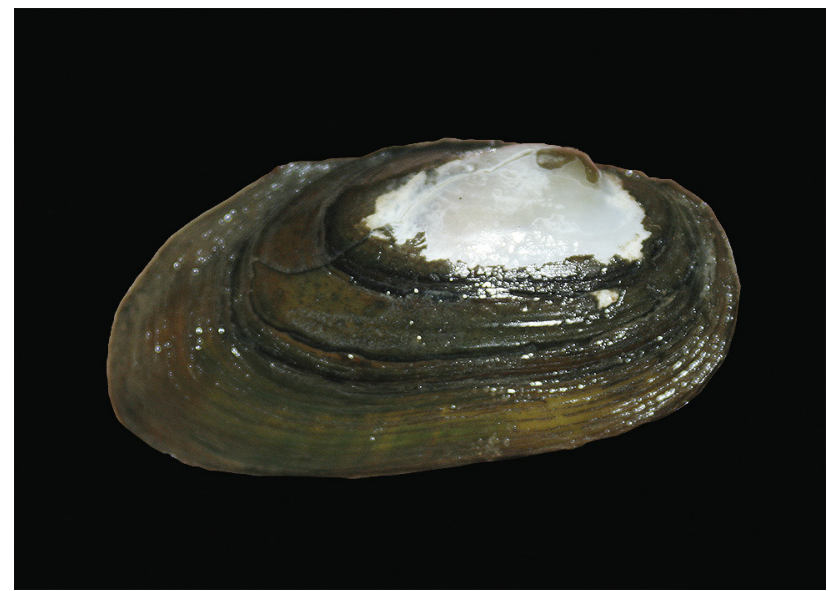

Fig. 2. Adult thick-shelled river mussel Unio crassus Philipsson, 1788 from the Stradomka river
Grabie village (208 $\mathrm{m}$ a.s.1.); it was not recorded upstream of this site. In the Trzciański stream the highest locality was Trzciana village (238 $\mathrm{m}$ a.s.l.). The only site in the Tarnawka river was in the environs of Boczów (234 $\mathrm{m}$ a.s.1.) and the only one in the Polanka was near Zalesie (216 m a.s.1.). One-year specimens were found in three sites in the Stradomka river; one well preserved one-year shell was recorded in the Tarnawka river. The number of observed individuals ranged from one to 86 . Habitats where $U$. crassus was found included gravel rapids, mud deposits within large stone artificial embankments and clay sediments (Fig. 3). Potential fish hosts of glochidia in these watercourses were L. cephalus and Phoxinus phoxinus. No other bivalves were found in the Stradomka and tributaries.

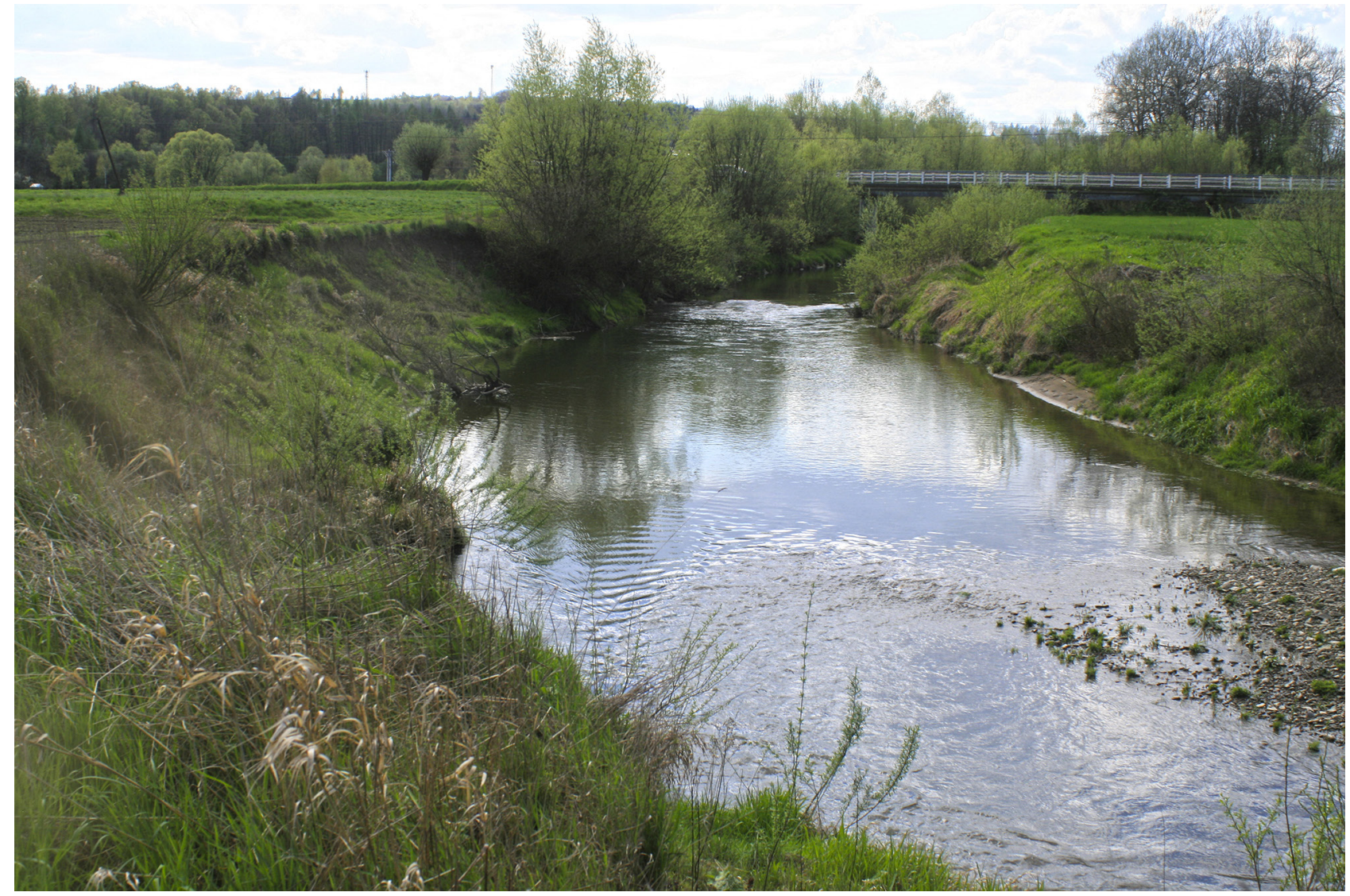

Fig. 3. One of natural microhabitats of the thick-shell river mussel Unio crassus Philipsson, 1788 in the Stradomka river external side of a meander with clay substratum

\section{DISCUSSION}

Recently, the number of known sites of $U$. crassus in Poland has increased. Most probably this is a result of growing interest in $U$. crassus as a "Natura 2000" species and inventory efforts following design and protection plans for "Natura 2000" sites. The quality of surface waters in Poland has improved in recent decades, which may have also allowed re-col- onisation of some areas by this clean-water mussel. Additionally, some of the watercourses have recovered after a large scale regulation, which also may have accelerated re-colonisation by U. crassus.

Records from the Stradomka river show that $U$. crassus may be widely distributed in the sub-Carpathian or Carpathian watercourses. In the upper 
Raba river, $U$. crassus is known only from one site near Pcim (BERGER 1973), but it is unknown if the species is still present there. BERGER (1973) did not detect it below the mouth of the Stradomka river near Chełm. However, recently several adults were found in the lower Raba river downstream of Cikowice commune (BONK 2016, unpublished), suggesting a wide distribution in the Raba and tributaries. Attempts to find $U$. crassus in the Stradomka near Łapanów in the last decade failed (K. \& T. ZAJAC, pers. comm. 2016). This may suggest a recent colonisation of the watercourse, however in that part of the river single specimens are found irregularly and could have gone undetected.

Despite the large scale regulation, i.e. construction and maintenance of embankments, the Stradomka river and its tributaries provide natural

\section{REFERENCES}

BERGER L. 1973. Mollusca of the River Raba and some of its tributaries. Acta Hydrobiol. 15: 401-411.

Bonk M., BudzIK K. M., BAś G., BudzIK K. A. 2014. New occurrence sites of the Noble Crayfish Astacus astacus in southern and western Poland. Chrońmy Przyr. Ojcz. 70: $452-457$.

DOUDA K., HORKÝ M., BíLÝ M. 2012. Host limitation of the thick-shelled river mussel: identifying the threats to declining affiliate species. Anim. Conserv. 15: 536-544. http://dx.doi.org/10.1111/j.1469-1795.2012.00546.x

DOUDA K., SELl J., KubÍKOVÁ-PELÁKOVÁ L., HORKÝ P. KACZMARCZYK A., MiODUCHOWSKA M. 2014. Host compatibility as a critical factor in management unit recognition: population-level differences in musselfish relationships. J. Appl. Ecol. 51: 1085-1095. http:// dx.doi.org/10.1111/1365-2664.12264

KORYCIŃSKA M. 2002. Molluscs of the Liwiec River (South Podlasie and Middle Mazovian Lowlands). Folia Malacol. 10: 17-23. http://dx.doi.org/10.12657/folmal.010.003

LEWANDOWSKI K., JAKUBIK B. 2014. Bivalves of the family Unionidae in the Krutynia river-lake system (Masurian Lakeland). Chrońmy Przyr. Ojcz. 70: 423-430.

LOPES-Lima M., SOUSA R., GeIST J., AldRidge D. C., ARAujo R., BERgENGREN J., Bespalaya Y., BóDis E., Burlakova L., VAN DAMme D., DOUda K., Froufe E., GEORGIEV D., GuMPINGER C., KARATAYEV A., KeBAPÇI Ü., Killeen I., LaJTNER J., LARSEN B. M., LAUCERI R., LEgAKIS A., LOIS S., LUNDBERG S., MOORKENS E., Motte G., Nagel K. O., Ondina P., Outeiro A., hydro-morphological conditions appropriate for $U$. crassus. Notably, despite the species being present near artificial river elements, almost only natural or re-naturalised parts of the river supported mussel concentrations (3-30 specimens in one microhabitat such as a clay patch or natural mud deposit). On the other hand, the presence of the mussel in various microhabitats suggests that the knowledge of habitat preferences and response to man-made river bed modifications require further studies.

The presence of $U$. crassus as well as other rare species (e.g. the noble crayfish Astacus astacus; BONK et al. 2014) in the Stradomka river is a strong argument in favour of avoiding riverbed modification or other construction works affecting natural river valley dynamics.

PAUnOVic M., PRIÉ V., ProschWitz T. VON, Riccardi N., Rudzite M., RudZiTIS M., SCHEDER C., SEDDON M., SEREFlisan H., Simic V., SOKOlOVA S., StOeCKL K., TAskinen J., TeiXeira A., Thielen F., TrichKova T., VARANDAS S., ViCENTINI H., ZAJAC K., ZAJAC T., ZOGARIS S. 2016. Conservation status of freshwater mussels in Europe: state of the art and future challenges. Biol. Rev. (in press) http://dx.doi.org/10.1111/ brv. 12244

MARZEC M. 2010. The thick-shelled river mussel Unio crassus in Romincka Forest's rivers. Folia Malacol. 18: 43-46. http://dx.doi.org/10.2478/v10125-010-0007-y

TAeubert J. E., Gum B., GeIst J. 2012. Host specificity of the endangered thick shelled river mussel (Unio crassus Philipsson, 1788) and implications for conservation. Aquat. Conserv. 22: 36-46. http://dx.doi.org/10.1002/ aqc. 1245

ZAJĄC K. 2004. Unio crassus Philipsson, 1788. Skójka gruboskorupowa. In: GŁOWACIŃSKI Z., NOWACKI J. (eds). Polska Czerwona Księga Zwierząt. Bezkręgowce. IOP PAN, AR im. Cieszkowskiego, Kraków, pp. 353-355.

ZAJĄC K. 2010. Skójka gruboskorupowa. Unio crassus Philipsson, 1788. In: MAKOMASKA-JUCHIEWICZ M. (ed.). Monitoring gatunków zwierząt. Przewodnik metodyczny. Część I. GIOŚ, Warszawa, pp. 157-179.

Received: July 18th, 2016

Revised: October 10th, 2016

Accepted: October 21 st, 2016

Published on-line: December 5th, 2016 